\title{
The Presence of Type 12 M-Protein Antigen in Group G Streptococci
}

\author{
By W. R. MAXTED \\ Cross-Infection Reference Laboratory, Central Public Health Laboratory, \\ Colindale, London, N.W.9 \\ AND ELIZABETH V. POTTER \\ Northwestern University, Chicago, Illinois, U.S.A. \\ (Accepted for publication 19 April 1967) \\ SUMMARY \\ Three strains of group $\mathrm{G}$ streptococci isolated from a community in which \\ glomerulonephritis is common were found to have an M-protein antigen \\ indistinguishable from the type I 2 M-protein of group A, type I2, streptococci.
}

\section{INTRODUCTION}

The M-antigen of Streptococcus pyogenes (the group A streptococcus) is an essential factor in the virulence of the organism as indicated by its ability to kill mice and to multiply in human blood; and antibodies to M-protein form the basis of type-specific immunity (Lancefield, 1962). Other protein antigens, such as the $T$ and $R$ antigens, which are commonly present in $S$. pyogenes, may also be found in streptococci of other Lancefield groups (Lancefield \& Dole, 1946; Crowley, 1944; Maxted, 1949, I953). The M-proteins, however, are generally believed to occur only in members of Lancefield group A and in variants of that group which have lost their A-carbohydrate (Wilson, 1945; McCarty \& Lancefield, 1955).

During the bacteriological investigation of a large epidemic of acute glomerulonephritis in Trinidad in 1965 (Simon et al. 1965), three strains of group G streptococci were isolated which appeared to possess the group A, type 12, M-protein. These three cultures formed part of a collection of streptococci of groups A, C and G isolated by one of us (E.P.) from patients with glomerulonephritis and from non-nephritic school children. The laboratory in Chicago found that one of the group $\mathrm{G}$ streptococci gave a strong precipitin reaction with $M$ I 2 antiserum. The $M I 2$ antigen in this strain and in the other two cultures described in this report was detected independently at Colindale during an investigation into the specificity of a highly absorbed fluorescent conjugate of group A, type 12 , antiserum (Heimer, 1966). Subsequently, two additional strains have been isolated and identified in Chicago. Because of the association with acute glomerulonephritis of group A streptococci which possess the MI2 antigen (Rammelkamp \& Weaver, 1952; Wilmers, Cunliffe \& Williams, 1954), it was of some importance to establish precisely the nature of the antigen present in these group $G$ streptococci. 


\section{METHODS}

Streptococci. Group G strains. Culture no. 2832 was isolated from the throat of a child with acute glomerulonephritis in San Fernando General Hospital, Trinidad. (A group A streptococcus, with no detectable $\mathrm{M}$-antigen, but with the $\mathrm{T}$-agglutination pattern 3/13/B 3264, was isolated from a skin sore of the same patient.) Cultures 2439 and 2440 were isolated from skin sores of children without nephritis during a school survey also in the San Fernando area. These three organisms had the type 12 antigen and will be referred to as $\mathrm{G} I 2$.

Group A strains. Culture no. 1077 was a type 12 laboratory strain originally isolated from a case of glomerulonephritis. Culture no. $4 \mathrm{I} 448$ was a mouse-virulent laboratory strain, also of type 12, originally isolated from a case of scarlet fever. Strain NCTC 8305 (type 24) was used as a control in bactericidal tests.

Media. A modified Todd-Hewitt broth was used; it was a meat infusion with buffer and glucose added, and the whole sterilized by heat.

Blood agar was Hartley digest agar $+7 \%$ (v/v) horse blood.

Bactericidal tests. Streptococci capable of multiplying in heparinized normal human blood are killed when small amounts of type-specific antiserum containing M-antibody are added. The test used here was essentially that described by Maxted (1956), except that the mixtures were rotated end-over-end at $37^{\circ}$ and $0.02 \mathrm{ml}$. samples inoculated into blood agar pour plates after $3-4 \mathrm{hr}$.

Antisera. These were made by injecting rabbits intravenously with washed wholecell vaccines made by concentrating $\mathrm{I} 8 \mathrm{hr}$ broth cultures tenfold and heating them to $60^{\circ}$ for I hr. A I ml. dose of this vaccine was given intravenously on two successive days each week for 8 weeks.

Antigen extracts. The overnight growth from $50 \mathrm{ml}$. of broth was extracted with $0.6 \mathrm{ml} .0 .2 \mathrm{~N}-\mathrm{HCl}$ in boiling water for Io min., cooled, neutralized with $0.2 \mathrm{~N}-\mathrm{NaOH}$ and centrifuged until clear.

Precipitin tests were done in capillary tubes by the method first described by Swift, Wilson \& Lancefield (1943).

Absorption of sera. For absorption with whole organisms, equal volumes of packed bacteria and serum were mixed, left for $4 \mathrm{hr}$ at $37^{\circ}$, and then centrifuged until clear.

Absorption with extracted antigen was done as follows. Four volumes of ethanol $(95 \%, \mathrm{v} / \mathrm{v}$ in water) were added to I volume of antigen extract. After centrifugation, the supernatant fluid was removed and the precipitate taken up in I volume of serum. The mixture was left at $37^{\circ}$ for $2 \mathrm{hr}$ and then at $4^{\circ}$ overnight before centrifuging until clear.

Double gel-diffusion. Five ml. of $\mathrm{I} \%$ (w/v) 'Oxoid' Ionagar No. 2 in water at $\mathrm{pH} 7.4$ was poured into Petri dishes of 2 in. diameter. Wells $4 \mathrm{~mm}$. in diameter were arranged radially $5 \mathrm{~mm}$. from a centre well.

Mouse-protection tests. White mice (18-20 g.) were given $0.25 \mathrm{ml}$. of serum intraperitoneally and challenged $24 \mathrm{hr}$ later with $0.5 \mathrm{ml}$. of a $16 \mathrm{hr}$ broth culture suitably diluted in saline with $10 \%(\mathrm{v} / \mathrm{v})$ of broth added.

Fluorescent staining. Smears were made directly from $16 \mathrm{hr}$ blood agar plate cultures, stained with a highly specific fluorescent conjugate of a group A, type I2, antiserum, and examined microscopically with illumination from a Mazda ME/D 250 W. mercury vapour lamp and a chance Pilkington O.X. I excitation filter with an Ilford $805 \mathrm{Q}$ barrier filter. 
RESULTS

Capillary precipitin tests were done with acid extracts of the three group $G$ strains and all the $\mathrm{M}$-antisera for Streptococcus pyogenes types available at Colindale (types I-3, 5, 6, 9, II I I2, I4, I 5, I 7-I9, 22-26, 29-3I, 33, 36, 37, 39, 4I, 43, 46-5I). All three precipitated with type 12 antiserum and with no other.

The extracted antigen from the group $G$ strain 2832 was precipitated with ethanol and used to absorb a sample of group A, type 12, M-antiserum made with strain 1077. The serum before and after absorption was tested against an acid extract of strain 1077 . The antigen from the group $\mathrm{G}$ strain completely removed the type $\mathrm{I} 2$ precipitating antibody from the serum (Table 1 ).

Table I. Removal of precipitating antibody, and of bactericidal power from a streptococcus group A, type I2, by absorption with streptococcus group $G$, type I2, protein

Bactericidal test : $0.3 \mathrm{ml}$. blood $+0.02 \mathrm{ml}$, serum $+0.02 \mathrm{ml}$. culture inoculum.

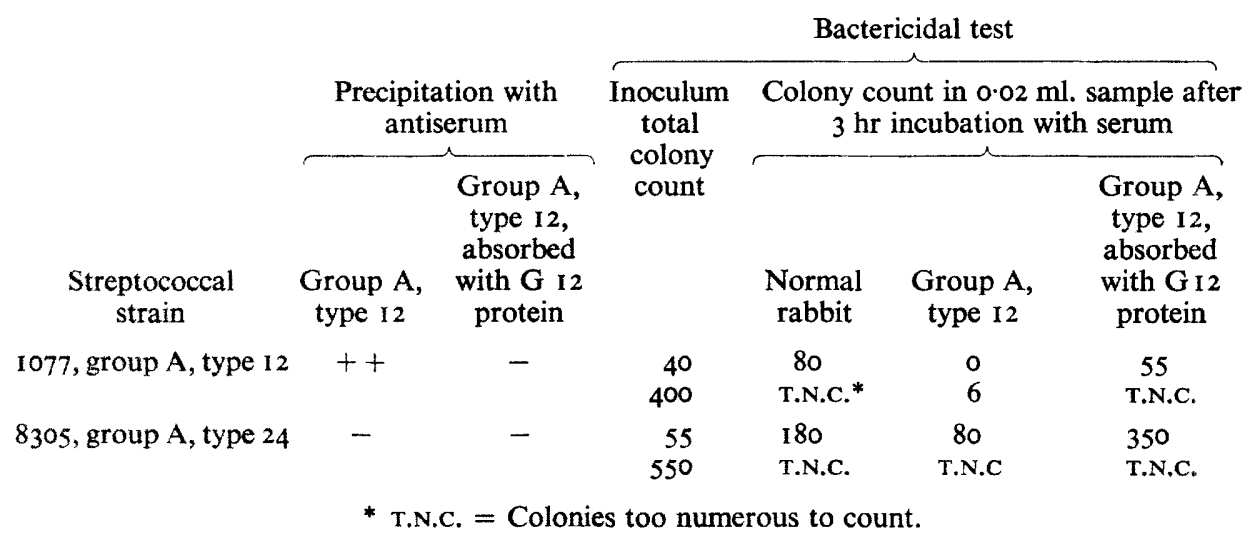

If this were a true $M$-antigen-antibody system, the bactericidal power of the serum, when added to normal human blood, should also be removed by the group $\mathrm{G}$ extract. Normal rabbit serum and group A, type 12, antiserum, before and after absorption with G 12 antigen, were each mixed with samples of heparinized normal human blood, and the killing efficiency of these mixtures tested against group A, type I2, streptococci. The bactericidal power of the group A, type I2, serum was removed by absorption with the GI2 antigen from strain 2832 (Table I). The group A, type 24, strain used as control grew unrestrictedly in all blood + serum mixtures.

The three group GI2 strains were each used as inocula in bactericidal tests with similar blood +serum mixtures and proved equally susceptible to the killing efficiency of group A, type 12, antiserum.

Antisera were made against each of the three group G, type I2, strains and tested for precipitating antibody against stock M-extracts of all known types of group A streptococci. The group A, type 12, extract reacted well with each of these sera, but no extract of any other type gave a similar precipitate. The sera were also tested for their bactericidal power against a group A, type I2, strain, a group A, type 24, strain, and also against each of the group $G$ vaccine strains. The bactericidal action of two of 
the antisera against the $A I 2$ and each of the $G I 2$ strains was good. The third antiserum, made against strain 2832 , was not so bactericidal, but showed some bacteriostatic effect. The results were reproducible with blood from several donors; one such test is shown in Table 2. In this test a single inoculum of each test strain was used throughout.

It was possible that the group $G$ strains might have two M-protein antigens, the A I 2 and another found only among group $G$ strains. If this were so, and the group $G$ cocci surviving in the bactericidal system did so because they possessed this second antigen, a mixture of the group A, type 12, antigen and the $\mathrm{G}_{12}$ antiserum in a single bactericidal system might be expected to give greater killing. Bactericidal tests done with such a mixture of antisera showed no greater killing than with either antiserum alone.

Table 2. A comparison of the bactericidal power of streptococcus group A, type I2, antiserum and antisera prepared against streptococcus group $G$, type 12 , strains

All samples received a single inoculum of the strain tested. This was $0.02 \mathrm{ml}$. of an $18 \mathrm{hr}$ culture diluted $10^{-4}$ and averaged 200-300 organisms for each strain.

\begin{tabular}{|c|c|c|c|c|c|c|}
\hline \multicolumn{2}{|c|}{ Streptococcus } & \multirow{2}{*}{$\begin{array}{c}\text { Normal } \\
\text { rabbit } \\
\text { serum }\end{array}$} & \multicolumn{4}{|c|}{ Antisera made with strains } \\
\hline \multirow[t]{2}{*}{ Strain } & $\begin{array}{l}\text { Group } \\
\text { and type }\end{array}$ & & $\begin{array}{l}2439 \\
G_{12}\end{array}$ & $\begin{array}{l}2440 \\
G \text { I } 2\end{array}$ & $\begin{array}{l}2832 \\
G_{12}\end{array}$ & $\begin{array}{l}1077 \\
A_{12}\end{array}$ \\
\hline & & \multicolumn{5}{|c|}{ Colony numbers } \\
\hline 41448 & A 12 & T.N.C.* & 31 & I & 1500 & 2 \\
\hline J17D & A 24 & T.N.C. & T.N.C & T.N.C. & T.N.C. & T.N.C. \\
\hline 2439 & GI2 & T.N.C. & 64 & 25 & 1000 & 23 \\
\hline 2440 & Gi2 & T.N.C. & 40 & 8 & 350 & 0 \\
\hline 2832 & G 12 & T.N.C. & 46 & 45 & 400 & 38 \\
\hline
\end{tabular}

Gel-diffusion tests were done to show the identity of the type antigens of the group $G$ and group A organisms. With group G, type I2, antiserum in the centre well and extracts of the A 12 and GI2 strains in the peripheral wells a strong and continuous line of identity was seen. When each of the G 12 antisera was tested in the centre well against similar extracts, a continuous line of identity was again seen, as well as several other lines of precipitation with the G 12 extracts (probably due to the group antibody, since these antisera were unabsorbed).

It has been shown repeatedly that anti-M sera, when injected into mice, give excellent passive protection against a subsequent challenge with a virulent group $\mathrm{A}$ streptococcus of homologous type. Antisera against the G 12 strains should therefore protect mice challenged with group A, type 12, streptococci. The group A and the group G antisera were tested against strain 41448 (group A, type I2). Mice in groups of 20 were each given $0.25 \mathrm{ml}$. of antiserum intraperitoneally $18 \mathrm{hr}$ before the inoculation of the virulent streptococci. The test was done with two dilutions of the challenge strain. The G 12 antisera protected mice as effectively as the group A, type 12, antiserum against fatal infection with the virulent group A, type 12, streptococci. The results of a representative test with one $G_{1} 2$ serum are shown in Table 3.

Because of the widely held belief that M-antigens are to be found only in group A streptococci, they have probably not been looked for extensively in members of other groups. A survey was therefore made of a larger number of group $\mathrm{G}$ strains, both from 
stock and freshly isolated, including many from Trinidad. The fluorescent staining, which had proved so sensitive and successful originally, was used as a screening test on 140 group $G$ and 10 group $C$ strains. Thirty-seven of the group $G$ and three of the group $\mathrm{C}$ strains, all isolated in Trinidad, were also extracted with acid and tested by the capillary precipitin test against all the available group A anti-M sera. No other strains were found which showed any relationship with group A organisms.

Table 3. The ability of streptococcus group A, type 12, antiserum and antiserum made against a streptococcus group $G$, type 12 , strain (2440) to protect mice challenged with a virulent group A, type I2, streptococcus

Challenge doses. One-half $\mathrm{ml}$. of $16 \mathrm{hr}$ broth culture diluted in saline $+10 \%(\mathrm{v} / \mathrm{v})$ broth. One-half $\mathrm{ml}$. of a $10^{-5}$ dilution of culture contained approximately 750 organisms.

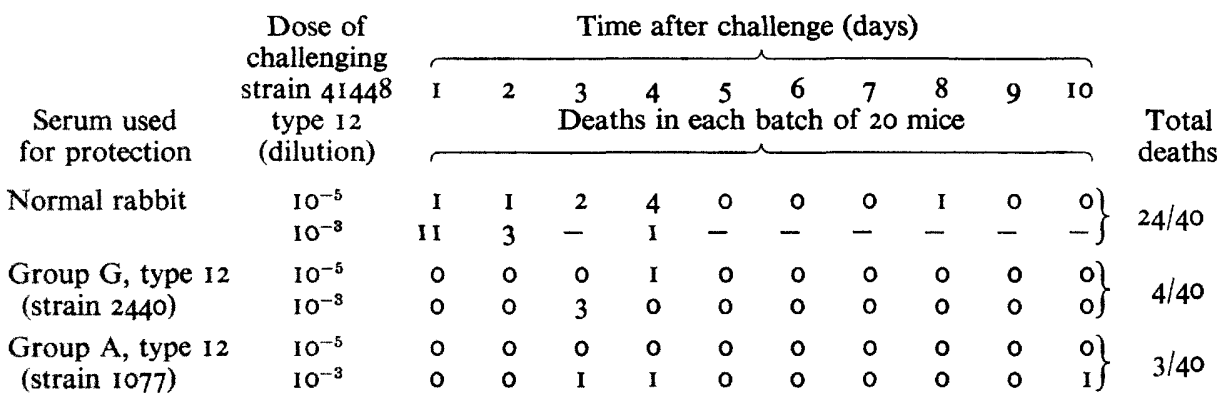

Experiments were made to see whether the G 12 strains were in fact group A strains with the unusual ability of synthesizing group $\mathrm{G}$ cell-wall or were true group $\mathrm{G}$ strains which formed type 12 M-protein.

(1) A cell-wall analysis of the three GI2 strains, kindly done by Mr G. Colman by the techniques applied by him to a large variety of streptococci (see Colman \& Williams, 1965) showed the presence of galactosamine and galactose, both characteristic of the group G streptococcal cell-wall but not found in group A streptococci.

(2) The phage-associated lysin (Maxted, 1957; Krause, 1958) which attacks the cell-wall of viable group A streptococci did not lyse the three G 22 strains.

(3) Group A strains resistant to bacitracin in the ' differentiation' disc test (Maxted, 1953) are, in our experience, very rare. All three of the GI2 strains were resistant to bacitracin.

(4) In an extensive experience of routine serological typing of Streptococcus pyogenes, we have found that organisms with the $M_{12}$ antigen are nearly always agglutinated by antisera prepared against the $T$ antigen of type 12 or type 10 . Suspensions of the $\mathrm{G} I 2$ strains were not agglutinated by antisera containing the $T$ antibodies of type 12 or type 10.

(5) Virulent and temperate phages which had been propagated on group A, type I2, streptococci and shown to be active on the majority of group A strains of type 12, did not lyse any of the three group G, type 12 , strains.

\section{DISCUSSION}

The evidence presented here suggests that strains 2832,2439 and 2440 belong to Lancefield group $\mathrm{G}$, but have the ability to synthesize type $12 \mathrm{M}$-antigen. It now seems 
possible that an infection with these or similar group $G$ streptococci might result in the production of protective antibody against certain members of group A, a possibility which had not previously seemed to need consideration. The ability of these group $G$ strains to establish an infection is, however, uncertain. Two of the strains were isolated from skin lesions, but there is no certainty that they were the cause of them, since the presence of two or more different streptococci in the skin lesion of the same patient is not uncommon (Barrow, 196I; Dr D. J. C. Bassett, personal communication; Anthony, Perlman \& Wannamaker, 1967). The third strain was isolated from the throat of a patient suffering from glomerulonephritis, but a group A streptococcus was isolated concurrently from a skin lesion. There is no conclusive evidence that the M-antigen of the group A, type 12, streptococcus is responsible for its ability to cause glomerulonephritis. The possibility cannot be excluded, however, that the nephritogenic factor might be associated closely with the type I 2 antigen either in Streptococcus pyogenes or in some other group of streptococci. The significance of these findings will remain uncertain until more is known about the ability of the various strains of $S$. pyogenes isolated in Trinidad to cause glomerulonephritis. It is certain, however, that group $\mathrm{G}$ streptococci with the $\mathrm{M}_{12}$ antigen form only a tiny minority of the streptococcal strains to be found in skin lesions and in the respiratory tract in Trinidad, and it is therefore unlikely that they are a common cause of either impetigo or glomerulonephritis. Their ability to multiply in whole human blood suggests, however, that they may be potentially virulent for man.

The G 12 organisms may prove useful in genetic studies of streptococci, but it is not yet possible to speculate about their origin. In general, it is our experience that strains of Streptococcus pyogenes showing undoubted evidence of M I 2 antigen are rarely isolated in Trinidad. At the Colindale laboratory we have recently examined serologically over 1000 cultures of $S$. pyogenes from Trinidad and did not find the M 12 antigen in any of them. Several were agglutinated by the T 12 antiserum, but they formed only a small minority of the strains isolated from cases of glomerulonephritis. Although we made a search for M-antigens among group $\mathrm{G}$ strains, the survey was a small one and was mainly for type $12 \mathrm{M}$-antigen, but there is no reason why $\mathrm{M}$-antigens of other types should not be found. A more extensive search for $\mathrm{M}$-antigens in streptococci of other Lancefield groups might be rewarding.

One of us (E.P.) received support for part of this study from grant no. USPHS 3585 ROI HE $07057-04$.

\section{REFERENCES}

Anthony, B. F., Perlman, L. V. \& Wannamaker, L. W. (1967). Skin infection and acuten ephritis in American Indian children. Pediatrics 39, 263.

Barrow, G. I. (196I). An outbreak of streptococcal infection caused by different strains. Mon. Bull. Minist. Hlth 20, 222.

Colman, G. \& Williams, R. E. O. (I965). The cell walls of streptococci. J. gen. Microbiol. 4I, 3.

Crowley, N. C. (1944). Hyaluronidase production by haemolytic streptococci of human origin. J. Path. Bact. 56, 28.

Heimer, G. V. (1966). Progress in Microbiological Techniques, ist ed. Ed. by C. H. Collins. London: Butterworth.

KRAUSE, R. M. (1958). Studies on the bacteriophage of hemolytic streptococci. II. Antigen released from the streptococcal cell-wall by phage associated lysin. J. exp. Med. ro8, 803 .

LANCEFIELD, R. C. (1962). Current knowledge of type-specific $M$ antigen of group A streptococci. J. Immun. 89, 307. 
LANCEfield, R. C. \& Dole, V. P. (1946). The properties of T antigen extracted from hemolytic streptococci. J. exp. Med. 84, 449 .

MCCARTY, M. \& LANCEFIELD, R. C. (1955). Variation in the group-specific carbohydrates of group A streptococci. I. Immunochemical studies on the carbohydrates of variant strains. J. exp. Med. ro2, II.

MAXTED, W. R. (1949). Occurrence of M substance of T 28 group A in streptococci of Lancefield groups B, C and G. J. gen. Microbiol. 3, I.

MAXTED, W. R. (1953). The use of bacitracin for identifying group A haemolytic streptococci J. clin. Path. 6, 224.

MAXTED, W. R. (1956). The indirect bactericidal test as a means of identifying antibody to the $\mathrm{M}$ antigen of Streptococcus pyogenes. Br. J. exp. Path. 37, 415 .

MAXrED, W. R. (1957). The active agent in nascent phage lysis of streptococci. J. gen. Microbiol. 16, 584 .

Rammelkamp, C. H. \& Weaver, R. S. (1952). Acute glomerulonephritis. The significance of the variation in the incidence of the disease. J. clin. Invest. 32, 345.

Simon, W. S., Potter, E. V., Siegel, A. C., McAninch, J., Poon-King, T., Humair, L. \& Earle, D. P. (1965). Epidemic nephritis in Trinidad. J. Lab. clin. Med. 66, 1022 .

SWIFT, H. F., Wilson, A. T. \& LANCEFIELD, R. C. (1943). Typing group A haemolytic streptococci by $M$ precipitin reactions in capillary pipettes. J. exp. Med. $78,127$.

Wilmers, M. J., Cunliffe, A. C. \& Williams, R. E. O. (I954). Type I 2 streptococci associated with acute haemorrhagic nephritis. Lancet ii, 17.

WiLSON, A.T. (1945). Loss of group carbohydrate during mouse passages of a group A hemolytic streptococcus. J. exp. Med. 81, 593. 